\title{
혈우병 $\mathrm{A}$ 형 환자에서 재조합 혈액응고인자 VIII (그린진주 ${ }^{\mathrm{TM}}$ )의 내약성 및 약동학적 특성에 관한 연구
}

${ }^{1}$ 서울대학교 의과대학 약리학교실, 서울대학교병원 임상약리학과, ${ }^{2}$ 주식회사 녹십자 종합연구소

한혜경 ${ }^{1}$, 신광희 ${ }^{1}$, 백상훈 ${ }^{2}$, 정재용 ${ }^{1}$, 임경수 ${ }^{1}$, 조주연 ${ }^{1}$, 윤서현 $^{1}$, 신상구 ${ }^{1}$, 장인진 ${ }^{1}$, 유경상 ${ }^{1}$

$=$ Abstract $=$

Pharmacokinetics and Tolerability Evaluation of Human Coagulation Recombinant Factor VIII $\left(\right.$ GreenGene $\left.^{\mathrm{TM}}\right)$ in Hemophilia A Patients

\author{
HyeKyung Han ${ }^{1}$, Kwang-Hee Shin ${ }^{1}$, Sang-Hoon Paik2 ${ }^{2}$ Jae-Yong Chung ${ }^{1}$, Kyoung Soo Lim', \\ Joo-Youn Cho ${ }^{1}$, Seo Hyun Yoon ${ }^{1}$, Sang-Goo Shin ${ }^{1}$, In-Jin Jang ${ }^{1}$, Kyung-Sang Yu ${ }^{1}$ \\ ${ }^{1}$ Department of Pharmacology and Clinical Pharmacology, Seoul National University College of Medicine and Hospital, \\ Seoul, Korea, ${ }^{2} G C-$ Research Center, Green Cross Corporation, Yongin, Korea
}

Background: GreenGene ${ }^{\mathrm{TM}}$ (Green Cross Corp.) is a recombinant clotting factor VIII which is used for hemophilia A. This study aimed to investigate the pharmacokinetics and safety profiles of $25 \mathrm{IU} / \mathrm{kg}$ and $50 \mathrm{IU} / \mathrm{kg}$ of GreenGene ${ }^{\mathrm{TM}}$ in Korean hemophilia A patients.

Methods: A dose-block randomized, single-blind, active drug-controlled, single and multiple dose, parallel-group study was conducted with 16 hemophilia A patients (25 IU/kg: $50 \mathrm{IU} / \mathrm{kg}=8: 8)$. They received GreenGene ${ }^{\mathrm{TM}}$ or GreenMono ${ }^{\mathrm{TM}}$ (active control) intravenously on day 1 and every other day from day 4 to 10. FVIII:C (Factor VIII procoagulant activity) was measured to determine the pharmacokinetics (PK) at baseline and up to 48 hours for single and multiple administration. PK parameters were determined using noncompartmental methods.

Results: The maximum concentration $\left(\mathrm{C}_{\max }\right)$ and the area under the concentration-time curve $\left(\mathrm{AUC}_{0-48}\right)$ of the GreenGene $25 \mathrm{IU} / \mathrm{kg}$ (mean $\pm \mathrm{SD}$ ) were $59.00 \pm 19.26 \%$ and $774.40 \pm 380.13 \% \cdot \mathrm{h}$ respectively, while those of $50 \mathrm{IU} / \mathrm{kg}$ were $131.50 \pm 39.81 \%$ and $1462.44 \pm 397.09 \% \cdot \mathrm{h}$ after single administration. The $\mathrm{C}_{\max }$ and $\mathrm{AUC}_{0-48}$ in steady state of the GreenGene ${ }^{\mathrm{TM}} 25 \mathrm{IU} / \mathrm{kg}$ were $68.17 \pm 22.75 \%$ and $863.30 \pm 334.40$ $\% \cdot \mathrm{h}$, while those of $50 \mathrm{IU} / \mathrm{kg}$ were $147.17 \pm 18.47 \%$ and $1820.08 \pm 704.42 \% \cdot \mathrm{h}$. No serious adverse event was observed.

Conclusion: The GreenGene ${ }^{\mathrm{TM}}$ to hemophilia A patients appeared to be well tolerated within range of 25-50 IU/kg. The PK parameters of factor VIII showed dose-independent manner with $25 \mathrm{IU} / \mathrm{kg}$ and 50 $\mathrm{IU} / \mathrm{kg}$ dose ranges.

Key words: Hemophilia A, Recombinant factor VIII, Pharmacokinetics, Korean

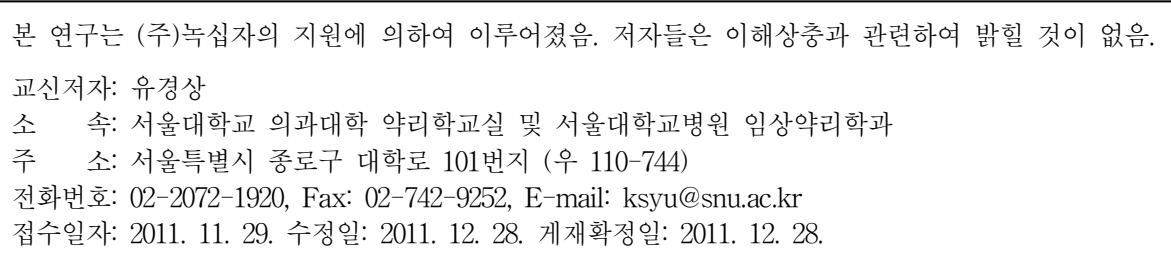




\section{서 론}

$\mathrm{A}$ 형 혈우병은 혈액응고인자 VIII의 결핍으로 나 타나는 출혈성 질환이다. 혈우병에는 $\mathrm{A}, \mathrm{B}, \mathrm{C}$ 의 세가지 형이 있는데, $\mathrm{A}$ 및 $\mathrm{B}$ 형은 반성 열성 유전 에 의해 남자에서 각각 혈액응고인자 VIII 또는 IX 이 결핍되어 발생하며, 혈우병 C는 autosomal recessive로 유전하는 혈액응고인자 XI 결핍에 의 한 출혈성 질환이다.,2) $\mathrm{A}$ 형은 국내 혈우병 환자 의 약 $80 \%$ 를 차지하는 것으로 알려져 있다. 혈 우병은 임상상으로 발치 후 과다 출혈, 피하 또는 근육 등의 심부혈종, 말초신경증이나 두개 내 출 혈 등에 의한 신경증상, 심부출혈에 의한 혈관 및 장기 압박 소견, 혈관절, 혈뇨, 비출혈 등의 다양 한 출혈 증상이 나타난다. 혈우병의 치료는 부족 한 혈액응고인자를 정맥주사를 통해 보충함으로 써 출혈을 사전에 예방하는 것이다. ${ }^{3)}$

$\mathrm{A}$ 형 혈우병의 치료제로 초기의 정상 성인의 신 선냉동혈장(Fresh Frozen Plasma)에서 혈액응고 인자 VIII 농축액까지, 사람의 혈장에서 추출한 혈 액응고인자 VIII을 주로 사용하여 왔다.,5) 그러나 이러한 치료제는 그 생산량에 한계가 있을 뿐 아 니라, 각종 바이러스 질환의 전파 경로가 될 가능 성이 있었다.6) 이러한 기존의 혈우병 치료제가 가 지고 있는 문제점들을 해결할 수 있는 대안으로 등장한 것이 유전자 재조합 기술을 이용한 혈액 응고인자 $\mathrm{VIII}$ 의 제조이다. ${ }^{7)}$ 그린진주 ${ }^{\mathrm{TM}}$ 는 $\mathrm{B}^{-}$ domain이 제거된 형태의 재조합 혈액응고인자로 분자량 약 $170 \mathrm{kDa}$ 이며 1,425 개의 아미노산 구조 로 이루어져 있다. 적응증은 혈액응고인자 VIII 결 핍으로 인한 $\mathrm{A}$ 형 혈우병의 치료이다.

본 연구에서는, 기존 혈액 유래 제제인 그린모 노-주 ${ }^{\mathrm{TM}}$ (녹십자)를 활성대조약으로 하여 재조합 혈액응고인자 VIII (그린진주 ${ }^{\mathrm{TM}}$, 녹십자)을 혈우병
$\mathrm{A}$ 형 환자에 단회 및 반복 정맥주입 후 안전성, 내약성 및 약동학적 특성을 평가하고자 하였다.

\section{연구대상 및 방법}

\section{1. 연구대상}

본 연구는 혈우병 지정병원에서 치료중인 만 12 세 이상의 $\mathrm{A}$ 형 혈우병 환자로서 과거 응고인자 치료경험이 100 일 이상이며, 혈액응고인자 VIII 수치가 $1 \%$ 미만인 16 명을 대상으로 하였다.

본 연구의 계획서 및 피험자 동의서는 서울대학 교병원 의학연구윤리심의위원회의 승인을 얻었고, KGCP (Korean Good Clinical Practice, 의약품임상 시험관리기준) 규정에 따라 수행되었다.

\section{2. 연구설계}

본 연구는 용량군별 무작위배정(dose-randomized), 단일 눈가림(single-blind), 평행 설계(parallel-group), 활성대조(active controlled), 단회 및 반복투여 (single and multiple dose) 형태로 진행되었다. 25 $\mathrm{IU} / \mathrm{kg}, 50 \mathrm{IU} / \mathrm{kg}$ 두 용량군에 대해 각 군당 8 명에게 시험약 또는 활성대조약을 $6: 2$ 로 무작위 배정하였다.

모든 피험자에 대해 투약 용량을 제외하고는 동일한 일정으로 진행되었다. 시험약 또는 활성대 조약을 단회투여 후 4일째부터 동일한 용량으로 7 일간 2일 1회 총 4회 반복투여(단회투여 포함 총 5 회) 하였다. 시험약 또는 활성대조약은 첨부된 용제에 투여직전 용해하여 최종부피가 $50 \mathrm{~mL}$ 가 되도록 하여 약 15 분간 정맥주사 하였다.

단회투여 후 약동학적 특성 검토를 위한 채혈은 투여 전, 투여 종료 시 $(0 \mathrm{~h})$, 종료 후 $5,15,30$ 분, 1 , $2,4,6,8,12,24,32,48$ 시간에 이루어졌으며, 반복 투여 후에는 투여 전, 투여 종료 시 $(0 \mathrm{~h})$, 종료 후 5 , 
15,30 분, $1,2,4,6,8,12,24,32,48,72$ 시간에 이루 어졌다. 채취한 혈액은 즉시 혈액응고 검사용 3.2 $\%$ sodium citrate tube에 담은 후 냉장 보관하였고, 채취 30 분 이내에 약 $4{ }^{\circ} \mathrm{C}, 1200 \mathrm{~g}$ 에서 10 분간 원심 분리한 후, 약 $1 \mathrm{~mL}$ 씩의 혈장시료 2 개를 취하여 분 석 시까지 $-70{ }^{\circ} \mathrm{C}$ 에 냉동 보관하였다. 약물동태 분 석을 위한 혈액응고인자 VIII 역가 측정은 One stage clotting assay 방법을 이용하였으며, 공인된 기관 들(Korean Society of Clinical Pathology 및 College of American Pathologist, $\mathrm{WHO}$ )에서 정도 관리를 받고 있는 서울대학교병원 진단검사의학과 에서 시행하였다.

안전성 확인을 위하여 예정된 일정에 따라 신 체검사, 활력징후 측정, 임상실험실 검사, 면역검 사 및 심전도 검사를 시행하였다. 자·타각 증상 등의 이상반응은 시험기간 중 피험자의 자발적인 보고 이외에 수시로 시험 담당자의 문진 등을 통 하여 확인하였다.

\section{3. 약동학적 평가}

본 연구에서는 그린진주 ${ }^{\mathrm{TM}}$ 의 약동학적 평가를 위하여 혈액응고인자 VIII의 활성을 측정하였으며, $\mathrm{FVIII:C로} \mathrm{나타내었다.} \mathrm{이는} \mathrm{응고인자의} \mathrm{역가를} \mathrm{측}$ 정하는 방법으로 정상인의 혈액응고인자 VIII과 비 교하여 sample의 양을 \%로 나타내며, 정상인 참 고치는 $60-140 \%$ 이다. 재조합 혈액응고인자 VIII 제제에 대한 활성도 분석에 관한 기존의 연구에 서 혈액응고인자 VIII 제제의 활성도는 약물의 농 도와 거의 유사한 특성을 보여 ${ }^{8)}$ 본 연구에서도 혈액응고인자 VIII 제제의 활성도 분석을 약동학적 분석으로 간주하고, 약동학 분석에 쓰이는 파라미 터를 사용하였다.

WinNonlin 4.1 (Pharsight Corporation, Cary, NC,
USA) 소프트웨어를 사용하여 비구획방법(noncompartmental model)을 이용하여 약동학적 파라미 터들을 분석하였다. 최고혈장농도(maximum observed plasma concentration, $\mathrm{C}_{\max }$ ), 최고혈장농도 도달시각 (time to maximum observed plasma concentration, $\left.\mathrm{T}_{\max }\right)$ 은 관측된 값을 사용하였다. 측정 가능한 마지 막 농도 측정치 $\left(\mathrm{C}_{48}\right)$ 를 포함하여 최소한 3개의 점을 포함한 보정된 결정계수(adjusted $r^{2}$ )가 최대가 되도 록 선형회귀하여 최종 소실속도상수(terminal elimination rate constant, $\lambda_{z}$ )를 구하였고 이로부터 최종 소실반감기 $\left(\mathrm{t}_{1 / 2}\right)$ 를 구하였다. $\mathrm{C}_{48}$ 까지의 혈장농 도-시간 곡선하 면적(area under the plasma concentration versus time curve from dosing to the last quantifiable concentration, $\left.\mathrm{AUC}_{0-48}\right)$ 을 $\mathrm{C}_{\max }$ 도 달 이전에는 사다리꼴 구간 적분(linear trapezoidal), $\mathrm{C}_{\max }$ 도달 이후에는 선형보간법(linear interpolation) 에 의해 산출하였다. 최종 채혈시각의 적절성을 확인 하기 위하여 $\mathrm{AUC}$ 에서 $\mathrm{AUC}_{0-48}$ 를 제외한 부분의 전 체 AUC에서의 비율(percent of AUC extrapolated, $\left.\mathrm{AUC}_{\text {Extrap }}\right)$ 을 구하였다. 이외에 소실속도 상수와 분 포용적의 곱으로 약물의 청소율 $(\mathrm{CL})$ 을 구하였으며, 반복 투여 후 48시간까지의 $\mathrm{AUC}_{0-48, \mathrm{ss}}$ 와 단회 투여 후 48시간까지의 $\mathrm{AUC}_{0-48}$ 의 비로 축적률(accumulation index, Ra)을 구하였다. 또한 각 파라미터의 군당 평 균, 표준편차 및 표준편차를 평균값으로 나눈 변이계 수(Coefficient of Variation, CV)를 구하였다.

\section{4, 내약성 평가}

신체검사, 임상실험실 검사(혈액학 및 혈액응고 검사, 혈액화학검사, 뇨검사), 면역검사, 심전도, 활 력증후, 이상반응 모니터링을 실시하였으며, 임상시 험 전 기간 동안 유해사례 발생을 모니터하였다. 
Table 1. Demographic data of subjects

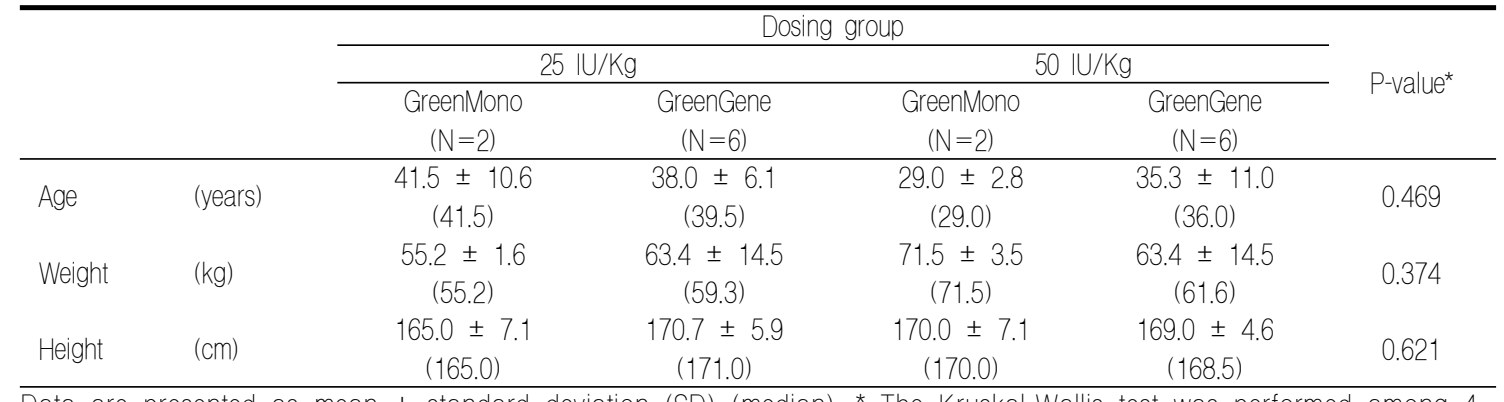

Data are presented as mean \pm standard deviation (SD) (median). * The Kruskal-Wallis test was performed among 4 treatment groups (25 $\mathrm{JU} / \mathrm{kg}, 50 \mathrm{lU} / \mathrm{kg}$ treatment and control groups).

\section{5. 통계분석}

통계분석은 $\mathrm{SAS}^{\circledR} 9.2$ (SAS Institute INC., Cary, North Carolina, USA) 소프트웨어를 사용하였다. 인구학적 정보의 경우, 나이, 체중, 신장에서 임상시 험 각 용량군 및 시험약과 활성대조약 군의 차이가 없음을 보이기 위하여 Kruskal-Wallis test를 사용 하여 평가하였다. 약동학적 파라미터는 피험자별 수치를 구한 후, 용량군 및 시험약과 대조약군별 평 균, 표준편차, 변이계수를 기술통계학적으로 제시하 였다. 또한 두 용량군간 전신 노출량 차이를 비교하

(a)

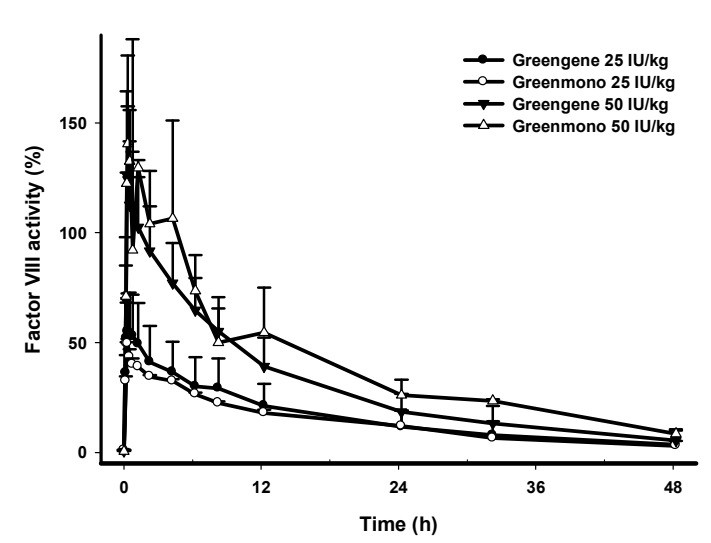

기 위하여 $\mathrm{AUC}_{0-48}$ 와 $\mathrm{C}_{\max }$ 를 투여용량으로 보정하 여 분석하였다. 단회투여 및 반복투여에서 시험약 두 용량군 간의 $\mathrm{AUC}_{0-48} / \mathrm{dose}, \mathrm{C}_{\max } / \mathrm{dose}$ 차이에 대 하여 각각 t-test를 사용하여 분석하였다.

\section{결 과}

각 용량군 및 시험약과 활성대조약 군에 배정 된 피험자 간에 나이, 체중, 신장 등 인구학적 특 성은 표1에 기술하였다(Table 1).

각 단회투여 및 반복투여에서 각 용량군별 시 간에 따른 평균 혈액응고인자 VIII 제제의 혈장 활

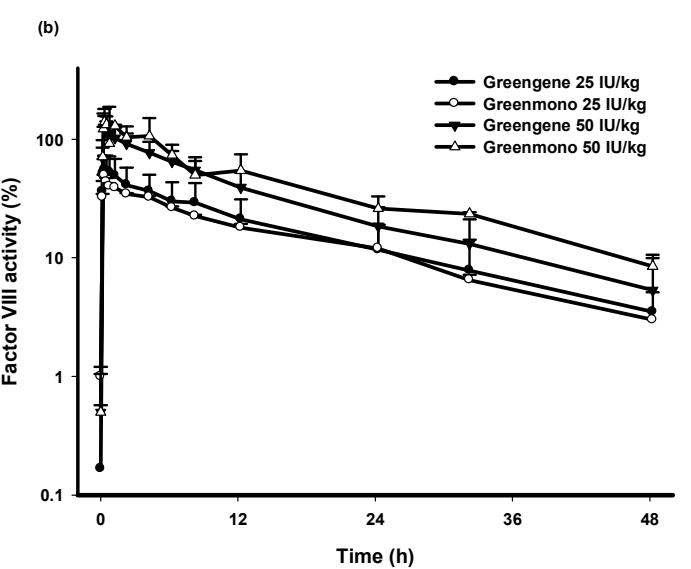

Figure 1. Mean Factor VIII (\%)-time profiles after single administration (a) linear scale, (b) log-scale. Bars represent standard deviations. 
Table 2. Plasma pharmacokinetic parameters after GreenGene or GreenMono single and multiple intravenous administrations

\begin{tabular}{|c|c|c|c|c|}
\hline \multirow{3}{*}{$\begin{array}{c}\text { Pharmacokinetic } \\
\text { parameters }\end{array}$} & \multicolumn{4}{|c|}{ Doses of GreenGene or GreenMono } \\
\hline & \multicolumn{2}{|c|}{$25 \mathrm{lU} / \mathrm{kg}$} & \multicolumn{2}{|c|}{$50 \mathrm{lU} / \mathrm{kg}$} \\
\hline & $\begin{array}{l}\text { GreenMono } \\
(N=2)\end{array}$ & $\begin{array}{l}\text { GreenGene } \\
\quad(N=6)\end{array}$ & $\begin{array}{c}\text { GreenMono } \\
(N=2)\end{array}$ & $\begin{array}{l}\text { GreenGene } \\
(N=6)\end{array}$ \\
\hline & & Single administration & & \\
\hline$T_{\max }(h)^{\dagger}$ & $\begin{array}{c}0.28 \\
\left(0.23^{-} \quad 0.33\right)\end{array}$ & $\begin{array}{c}0.32 \\
\left(0.17^{-}-0.52\right)\end{array}$ & $\begin{array}{c}0.55 \\
(0.35-0.75)\end{array}$ & $\begin{array}{c}0.29 \\
(0.25-0.35)\end{array}$ \\
\hline $\mathrm{C}_{\max }(\%)$ & $\begin{array}{c}50.00 \pm 1.41 \\
(2.83)\end{array}$ & $\begin{array}{c}59.00 \pm 19.26 \\
(32.60)\end{array}$ & $\begin{array}{c}164.50 \pm 6.36 \\
(3.87)\end{array}$ & $\begin{array}{c}131.50 \pm 39.81 \\
(30.27)\end{array}$ \\
\hline$t_{1 / 2}(h)$ & $\begin{array}{c}13.24 \pm 0.67 \\
(5.04)\end{array}$ & $\begin{array}{c}13.53 \pm 2.36 \\
(18.85)\end{array}$ & $\begin{array}{c}13.69 \pm 0.74 \\
(5.43)\end{array}$ & $\begin{array}{c}11.41 \pm 3.59 \\
(31.50)\end{array}$ \\
\hline$A \cup C_{0-48}(\% * h)$ & $\begin{array}{c}670.92 \pm 92.56 \\
(13.80)\end{array}$ & $\begin{array}{c}774.40 \pm 380.13 \\
(49.09)\end{array}$ & $\begin{array}{c}1908.66 \pm 482.54 \\
(25.28)\end{array}$ & $\begin{array}{c}1462.44 \pm 397.09 \\
(27.15)\end{array}$ \\
\hline$A \cup C_{\% \text { Extrap }}(\%)$ & $\begin{array}{c}7.91 \pm 0.64 \\
(8.09)\end{array}$ & $\begin{array}{c}7.57 \pm 1.41 \\
(18.65)\end{array}$ & $\begin{array}{c}8.09 \pm 0.43 \\
(5.30)\end{array}$ & $\begin{array}{c}5.82 \pm 4.79 \\
(82.25)\end{array}$ \\
\hline$C L(I U / \% * h)$ & $\begin{array}{c}1.91 \pm 0.31 \\
(16.05)\end{array}$ & $\begin{array}{c}2.85 \pm 2.92 \\
(102.42)\end{array}$ & $\begin{array}{c}1.79 \pm 0.35 \\
(29.59)\end{array}$ & $\begin{array}{c}2.09 \pm 0.74 \\
(35.26)\end{array}$ \\
\hline \multicolumn{5}{|l|}{ Multiple administration } \\
\hline$T_{\max , s s}(h)^{\dagger}$ & $\begin{array}{c}0.38 \\
(0.25-0.50)\end{array}$ & $\begin{array}{c}0.32 \\
(0.32-2.28)\end{array}$ & $\begin{array}{c}0.32 \\
(0.32-0.32)\end{array}$ & $\begin{array}{c}0.30 \\
(0.25-0.48)\end{array}$ \\
\hline $\mathrm{C}_{\max , \mathrm{ss}}(\%)$ & $\begin{array}{c}64.00 \pm 9.90 \\
(15.47)\end{array}$ & $\begin{array}{c}68.17 \pm 22.75 \\
(33.38)\end{array}$ & $\begin{array}{c}139.00 \pm 1.41 \\
(1.02)\end{array}$ & $\begin{array}{c}147.17 \pm 18.47 \\
(12.55)\end{array}$ \\
\hline$t_{1 / 2, s s}(h)$ & $\begin{array}{c}14.07 \pm 0.78 \\
(5.55)\end{array}$ & $\begin{array}{c}13.29 \pm 2.46 \\
(18.53)\end{array}$ & $\begin{array}{c}14.85 \pm 0.64 \\
(4.34)\end{array}$ & $\begin{array}{c}12.61 \pm 3.63 \\
(28.83)\end{array}$ \\
\hline$A \cup C_{0-48}(\% \star h)$ & $\begin{array}{c}711.21 \pm 12.11 \\
(1.70)\end{array}$ & $\begin{array}{c}863.30 \pm 334.40 \\
(38.73)\end{array}$ & $\begin{array}{c}2031.17 \pm 1.72 \\
(0.08)\end{array}$ & $\begin{array}{c}1820.08 \pm 704.42 \\
(38.70)\end{array}$ \\
\hline$A \cup C_{0-72}(\% * h)$ & $\begin{array}{c}752.87 \pm 20.75 \\
(2.76)\end{array}$ & $\begin{array}{c}929.85 \pm 371.59 \\
(39.96)\end{array}$ & $\begin{array}{c}2221.47 \pm 49.49 \\
(2.23)\end{array}$ & $\begin{array}{c}1945.21 \pm 811.62 \\
(41.72)\end{array}$ \\
\hline$A \cup C_{\% \text { Extrap }}(\%)$ & $\begin{array}{c}2.62 \pm 0.07 \\
(2.72)\end{array}$ & $\begin{array}{c}2.94 \pm 0.89 \\
(30.13)\end{array}$ & $\begin{array}{c}3.27 \pm 0.27 \\
(21.56\end{array}$ & $\begin{array}{c}2.71 \pm 2.85 \\
(105.42)\end{array}$ \\
\hline $\mathrm{CL}_{\text {ss }}(\mathrm{IU} / \% * h)$ & $\begin{array}{c}1.78 \pm 0.003 \\
(0.15)\end{array}$ & $\begin{array}{c}1.95 \pm 1.21 \\
(61.03)\end{array}$ & $\begin{array}{c}1.56 \pm 0.12 \\
(7.90)\end{array}$ & $\begin{array}{c}1.78 \pm 0.89 \\
(50.00)\end{array}$ \\
\hline $\mathrm{Ra}^{*}$ & 0.83 & 1.07 & 1.10 & 0.97 \\
\hline
\end{tabular}

Data are presented as mean \pm standard deviation (Coefficient of Variation \%) except for $\mathrm{T}_{\max }{ }^{\dagger}$. $\$$ Ra (Accumulation Index $=$ AUC $0-48,5 s / \mathrm{AUC}_{0-48}$.

성도를 그래프로 나타내었다(Figure 1, Figure 2). 단회투여에서 $25 \mathrm{IU} / \mathrm{kg}, 50 \mathrm{IU} / \mathrm{kg}$ 의 $\mathrm{T}_{\max }$ 의 중 앙값은 $0.32,0.29$ 시간이고, $\mathrm{C}_{\max }$ (평균 \pm 표준편 차)는 $59.00 \pm 19.26,131.50 \pm 39.81(\%), \mathrm{t}_{1 / 2}$ 은 $12.53 \pm 2.36,11.41 \pm 3.59$ 시간이었다. $\mathrm{AUC}_{0-48}$ 는 각각 $774.40 \pm 380.13,1462.44 \pm 397.09(\% * \mathrm{~h})$ 이며 $\mathrm{CL}$ 은 $2.85 \pm 2.92,2.09 \pm 0.74(\mathrm{IU} / \% * \mathrm{~h})$ 였
다. 반복투여에서 $25 \mathrm{IU} / \mathrm{kg}, 50 \mathrm{IU} / \mathrm{kg}$ 의 $\mathrm{T}_{\max }$ 의 중앙값은 $0.32,0.30$ 시간이고, $\mathrm{C}_{\mathrm{max}, \mathrm{ss}}$ 는 $68.17 \pm$ $22.75,147.17 \pm 18.47(\%), \mathrm{t}_{1 / 2}$ 은 $13.29 \pm 2.46$, $12.61 \pm 3.63$ 시간이었다. $\mathrm{AUC}_{0-48, s 5}$ 는 각각 863.30 $\pm 334.40,1820.08 \pm 704.42(\% * h)$ 이며, CL은 1.95 $\pm 1.21,1.78 \pm 0.89$ (IU/\%*h)였다(Table 2). $\mathrm{AUC}_{\% \text { Extrap }}$ 는 단회 및 반복투여에서 $25 \mathrm{IU} / \mathrm{kg}, 50$ 

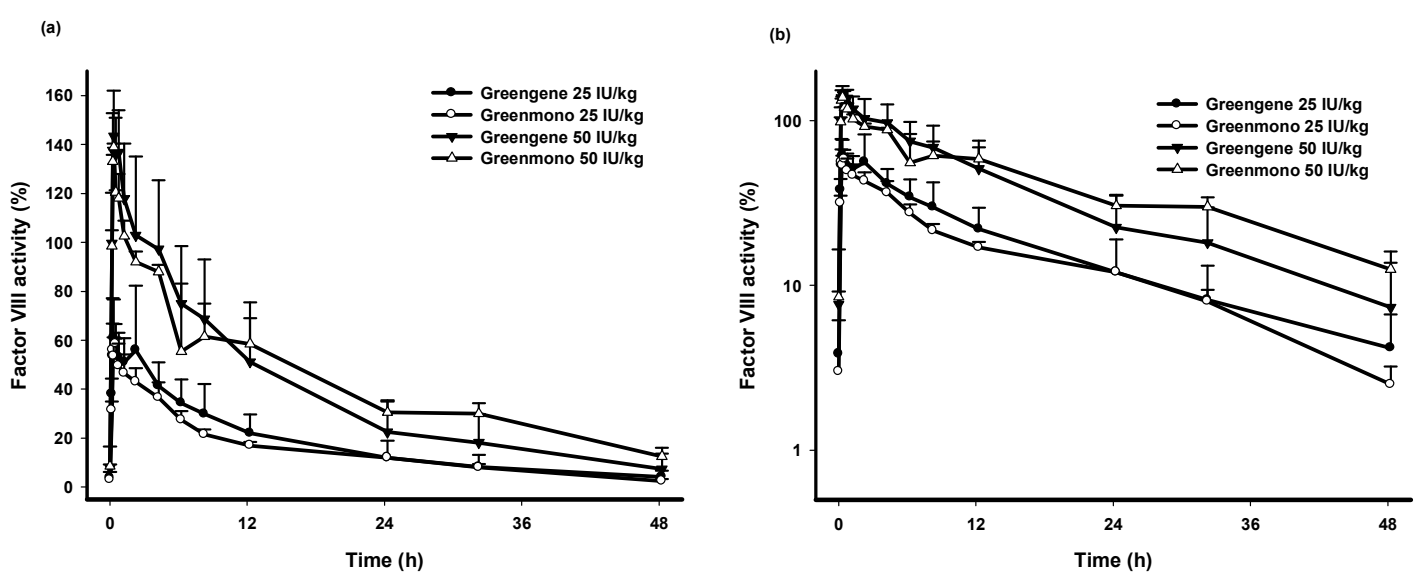

Figure 2. Mean Factor VIII (\%)-time profiles after multiple administration (a) linear scale, (b) log-scale. Bars represent standard deviations.

$\mathrm{IU} / \mathrm{kg}$ 용량군 각각 $7.57 \pm 1.41,5.82 \pm 4.79,2.94$ $\pm 0.89,2.71 \pm 2.85(\% * \mathrm{~h})$ 으로 나타나 약동학적 파라미터 산출을 위한 최종 채혈시간이 적절함을 확인하였다. 그린진주 ${ }^{\mathrm{TM}}$ 의 용량에 따른 체내 노출 정도를 비교한 결과 큰 차이를 보이지 않았다. $\mathrm{C}_{\max } /$ dose의 경우 단회투여에서 $25 \mathrm{IU} / \mathrm{kg}, 50$ $\mathrm{IU} / \mathrm{kg}$ 각각 $0.04 \pm 0.02,0.04 \pm 0.01(\% / \mathrm{IU})$ 였 고, 반복투여에서 $0.04 \pm 0.01,0.05 \pm 0.01(\% / \mathrm{IU})$ 였다. $\mathrm{AUC}_{0-48} / \mathrm{dose}$ 의 경우에는 단회투여에서 25 $\mathrm{IU} / \mathrm{kg}, 50 \mathrm{IU} / \mathrm{kg}$ 각각 $0.52 \pm 0.27,0.50 \pm 0.16$ $(\% * \mathrm{~h} / \mathrm{IU})$ 였고, 반복투여에서 $0.56 \pm 0.20,0.62 \pm$ $0.25(\% * \mathrm{~h} / \mathrm{IU})$ 였다(Table 3$)$.
약물이 체내 축적되는지 여부 및 축적 정도를 평가하기 위하여 반복투여시 축적률( $\mathrm{Ra})$ 을 평가 하였다. 본 연구에서 Ra 값은 $0.97-1.07$ 로 본 시험에서의 용법(2일 1 회)에서 의미있는 체내 축 적이 일어나지 않음을 확인하였다. 또한 활성대조 약의 $\mathrm{Ra}$ 역시 0.83 - 1.10 로 2일 1회 용법에서 체내 축적이 일어나지 않았다(Table 2).

약물 투여 용량이 증가함에 따라 $\mathrm{C}_{\max }$ 와 $\mathrm{AUC}$ 가 증가하는 양상을 보였다. 약물노출과 용량간의 관계를 보기 위하여 $\mathrm{C}_{\max }$ 와 $\mathrm{AUC}_{0-48}$ 를 비교하였 고, 용량에 따른 차이는 보정하였다. 그린진주 ${ }^{\mathrm{TM}}$ 의 용량군간 $\mathrm{C}_{\max } / \mathrm{dose}$ 와 $\mathrm{AUC}_{0-48} / \mathrm{dose}$ 의 차이를

Table 3. Comparison of dose-normalized $C_{\max }$ and $A U C_{0-48}$ between $25 \mathrm{IU} / \mathrm{kg}$ group and $50 \mathrm{IU} / \mathrm{kg}$ group after single or multiple administration

\begin{tabular}{|c|c|c|c|}
\hline & $25 \mathrm{IU} / \mathrm{kg}$ & $50 \mathrm{IU} / \mathrm{kg}$ & P-value ${ }^{*}$ \\
\hline Single administration & $N=6$ & $N=6$ & \\
\hline $\begin{array}{l}\mathrm{C}_{\max } / \text { Dose }(\% /(U) \\
\text { AUCo-48/Dose }(\% * h / I U)\end{array}$ & $\begin{array}{l}0.04 \pm 0.02 \\
0.52 \pm 0.27\end{array}$ & $\begin{array}{l}0.04 \pm 0.01 \\
0.50 \pm 0.16\end{array}$ & $\begin{array}{l}0.678 \\
0.835\end{array}$ \\
\hline Multiple administration & $N=6$ & $N=6$ & \\
\hline $\begin{array}{l}C_{\max } / \text { Dose }(\% / / U) \\
\text { AUC-48 }_{0-40 s e}\left(\% \%^{*} / / U\right)\end{array}$ & $\begin{array}{l}0.04 \pm 0.01 \\
0.56 \pm 0.20 \\
\end{array}$ & $\begin{array}{l}0.05 \pm 0.01 \\
0.62 \pm 0.25 \\
\end{array}$ & $\begin{array}{l}0.392 \\
0.661\end{array}$ \\
\hline
\end{tabular}


비교했을 때, 유의한 차이를 보이지 않아 약동학 적 선형성을 확인하였다(단회 투여 시 $\mathrm{P}=0.678$, 0.835 , 반복투여시 $\mathrm{P}=0.392,0.661)$.

임상연구 기간 동안 전체 16 명의 피험자 중 8 명 에서 총 9건의 이상반응(Adverse Event, $\mathrm{AE}$ )이 발 생하였다. 이중 그린진주 ${ }^{\mathrm{TM}}$ 혹은 그린모노-주 ${ }^{\mathrm{TM}}$ 와 의 인과관계가 있다고 판단되는 이상반응은 5 건으 로, '가려움증(itching)', '열감(febrile sense)', '졸림 (drowsiness)', '혈중 GTP 상승', '안구통(eyeball pain)'이었다. 대부분 경증이었고 모두 일시적이고 치료 없이 자발적으로 해소되었다. 중대한 이상반 응(Serious AE)은 발생하지 않았다. 또한 임상시험 기간 중 혈액학적 검사, 혈액응고검사, 혈액화학 검 사, 뇨검사, 심전도 검사, 활력징후, 신체검사 및 면 역검사 결과, 임상적으로 의미 있는 변화는 관찰되 지 않았다.

\section{고 찰}

본 연구에서는 기존 혈액 제제인 그린모노-주

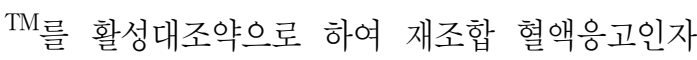
$\mathrm{VII}\left(\right.$ 그린진주 ${ }^{\mathrm{TM}}$, 녹십자)을 혈우병 $\mathrm{A}$ 형 환자에 단 회 및 반복 정맥주입 후 안전성, 내약성 및 약동 학적 특성을 평가하였다.

시험약(그린진주 $\left.{ }^{\mathrm{TM}}\right) 25 \mathrm{IU} / \mathrm{kg}$ 군의 단회투여 시 청소율에서 변이계수 $(\mathrm{CV})$ 값이 큰데(100.57 $\%)$, 그 원인으로 한 피험자(GC8006)의 청소율이 다른 피험자들에 비하여 크기 때문이다 (CLGC8006: $8.43 \mathrm{IU} / \% * \mathrm{~h}$, 나머지 5명 피험자들 의 평균 청소율: $1.41 \mathrm{IU} / \% * \mathrm{~h}) . \mathrm{GC} 8006$ 피험자의 소실반감기는 다른 피험자들과 비슷한데 반해, $\mathrm{F}$ $\mathrm{VIII:C}$ 값이 전체적으로 다른 피험자들에 비해 작 아 청소율이 크게 산출되었다. 이에 대한 원인으 로 체중 차이에 따른 혈중 농도 감소 혹은 혈액
응고인자 저해인자의 생성으로 인한 혈중 농도 감소를 고려할 수 있다. $\mathrm{GC} 8006$ 피험자는 다른 피험자들과 비교하여 체중이 컸지만, 투여용량은 체중에 비례하였으므로 체중으로 인한 혈중 농도 감소는 배제할 수 있다. 다른 원인으로 혈액응고 인자 VIII 저해인자 생성에 의한 영향을 고려할 수 있으나, ${ }^{9)}$ 모든 피험자에서 혈액응고인자 VIII 저해 인자가 생성되지 않았으므로 저해인자 생성에 의 한 영향 또한 낮다. 나이를 포함하여 혈액 검사에 서도 다른 피험자들과 다른 특이사항을 발견할 수 없어, 본 연구에서 평가하지 않은 다른 요인으 로 인한 개체차가 청소율 차이의 원인일 것으로 생각된다.

혈우병 A형 환자에서 혈액응고인자 저해인자 발생 빈도는 $3.8 \%$ 로 보고되었다. ${ }^{10)}$ 저해인자의 생성은 치료의 성공률을 저해하고 치료의 비용을 증가시킨다. ${ }^{11,12)}$ 본 연구에 참여한 모든 피험자에 서 혈액응고인자 저해인자가 생성되지 않았고, 특 이한 알러지 반응을 보인 피험자는 없었다. 그러 나 본 연구가 적은 수의 피험자를 대상으로 한 연구라는 점을 감안할 때, 대규모의 환자를 대상 으로 저해인자 생성에 평가를 고려해볼 수 있다.

본 연구 결과 보고된 이상반응은 대부분 경증 으로 치료 없이 소실되었으며, 한국인 자원자에서 그린진주 $^{\mathrm{TM}}$ 단회 및 반복 투여 시 $25 \mathrm{IU} / \mathrm{kg}$ 에서 $50 \mathrm{IU} / \mathrm{kg}$ 용량범위에서 내약성을 확인하였다.

재조합 혈액응고인자 $\mathrm{VII}\left(\right.$ 그린진주 ${ }^{\mathrm{TM}}$ )는 기존에 사용되고 있던 그린모노-주 ${ }^{\mathrm{TM}}$ 와 비교하였을 때 유사한 약동학적 특징을 가지고 있다(Table 2). 한 용량군에서 시험약을 투여 받은 피험자 수는 6 명, 활성대조약을 투여 받은 피험자 수는 2 명이 므로, 시험약과 활성대조약의 약동학적 특성을 비 교하는 것은 한계가 있다. 그러나 본 연구에서의 일차 목적은 시험약인 재조합 혈액응고인자 VIII 
(그린진주 ${ }^{\mathrm{TM}}$ )의 약동학적 특성을 평가하고자 함이 었으며, 이차적으로 활성대조약인 기존의 혈액응 고인자 VIII 제제 그린모노-주 ${ }^{\mathrm{TM}}$ 를 탐색적으로 비 교하고자 하였으므로, 확증적 연구를 위한 피험자 수가 필요하지는 않다고 판단하였다.

본 연구는 환자를 대상으로 한 연구라는 점에서 의의가 있다. 그러나 연구에서 교차(Cross-over)가 진행되지 않아 개개인의 차이가 결과에 반영될 수 있다는 단점을 지닌다. 환자의 나이, 이전 치료 경 험, 약동학적 평가시의 출혈 여부 등이 혈액응고인 자 VIII 제제의 혈장 활성도에 영향을 줄 수 있다고 알려져 있으나 ${ }^{13)}$ 본 연구에서는 나이, 이전 치료경 험 여부 등이 무작위 배정되었으며 출혈이 있었던 환자는 없어, 이에 대한 개인차 가능성은 낮다고 판단하였다.

$\mathrm{A}$ 형 혈우병 환자를 대상으로 한 본 연구에서는 재조합 혈액응고인자 VIII (그린진주 ${ }^{\mathrm{TM}}$ )의 약동학적 특성을 확인하였다. 또한 재조합 혈액응고인자 VIII (그린진주 ${ }^{\mathrm{TM}}$ )는 $25 \mathrm{IU} / \mathrm{kg}$ 에서 $50 \mathrm{IU} / \mathrm{kg}$ 용량내에 서의 내약성을 확인하였다.

\section{참고문헌}

1. White GC, 2nd, Shoemaker CB. Factor VIII gene and hemophilia A. Blood, 1989;73(1):1-12.

2. Oldenburg J, El-Maarri O. New insight into the molecular basis of hemophilia A. Int J Hematol, 2006;83(2):96-102.

3. Bjorkman S, Berntorp E. Pharmacokinetics of coagulation factors: clinical relevance for patients with haemophilia. Clin Pharmacokinet, 2001; 40(11):815-832

4. Gringeri A, Muca-Perja M, Mangiafico L, von Mackensen S. Pharmacotherapy of haemophilia A. Expert Opin Biol Ther, 2011;11(8):1039-1053.

5. Mannucci PM. Back to the future: a recent history of haemophilia treatment. Hemophilia, 2008;14 Suppl 3:10-18.

6. Lusher JM, Lee CA, Kessler CM, Bedrosian CL. The safety and efficacy of B-domain deleted recombinant factor VIII concentrate in patients with severe haemophilia A. Hemophilia, 2003; 9(1):38-49.

7. Pipe SW. Recombinant clotting factors. Thromb Haemost, 2008;99(5):840-850.

8. Goodeve AC, Rosen S, Verbruggen B. Haemophilia A and von Willebrand's disease. Haemophilia, 2010;16 Suppl 5:79-84.

9. Franchini M, Lippi G. Von Willebrand factor-containing factor VIII concentrates and inhibitors in haemophilia A. A critical literature review. Thromb Haemost, 2010;104(5):931-940.

10. Darby SC, Keeling DM, Spooner RJ, Wan Kan S, Giangrande PL, Collins PW, et al. The incidence of factor VIII and factor IX inhibitors in the hemophilia population of the UK and their effect on subsequent mortality, 1977-99. J Thromb Haemost, 2004;2(7):1047-1054.

11. Gringeri A, Mantovani LG, Scalone L, Mannucci PM. Cost of care and quality of life for patients with hemophilia complicated by inhibitors: the COCIS Study Group. Blood, 2003;102(7):2358-2363.

12. Martinowitz U, Bjerre J, Brand B, Klamroth R, Misgav M, Morfini M, et al. Bioequivalence between two serum-free recombinant factor VIII preparations (N8 and ADVATE(R))--an open-label, sequential dosing pharmacokinetic study in patients with severe haemophilia A. Hemophilia, 2011;17(6):854-859.

13. Bjorkman S, Folkesson A, Jonsson S. Pharmacokinetics and dose requirements of factor VIII over the age range 3-74 years: a population analysis based on 50 patients with long-term prophylactic treatment for haemophilia A. Eur J Clin Pharmacol, 2009;65(10): 989-998. 